\title{
Autotrophic Biological Transformations of Nitrogen under Oxygen-stressed and Anaerobic Conditions
}

\author{
JOSEPH D. ROUSE, HIROSHI ODA and KENJI FURUKAWA \\ Department of Civil Engineering and Architecture, \\ Faculty of Engineering, Kumamoto University, \\ Kurokami 2-39-1, Kumamoto 860, Japan
}

\begin{abstract}
Microorganisms have demonstrated considerable versatility in cycling nitrogenous compounds in natural and engineered environments. Experiments were conducted to study the controllability and potential applications of these less commonly considered phenomena. Stressed biological systems, lacking oxygen and labile organic compounds, with reduced and oxidized nitrogen substrates were investigated. Results demonstrated conversions of soluble nitrogenous compounds that could not be fully explained by traditional nitrification or denitrification. Comparisons are made to reports of others and discussed in terms of environmental engineering significance and items of interest that merit further inquiry are identified.
\end{abstract}

Key words : ammonium, hydroxylamine, nitrite, nitrate, nitrification, denitrification, nitrogenous compounds

\section{INTRODUCTION}

Literature Review Exceptions to the traditionally held routes of aerobic autotrophic nitrification and anoxic heterotrophic denitrification as explanations for nitrogen transformations in aqueous environments have become more and more common in recent years. Such phenomenon as heterotrophic nitrification and aerobic denitrification cannot be ruled out as potentially significant factors in the environmental cycling of nitrogen. ${ }^{\left.1{ }^{2}\right)}$ Also of significance are the apparent simultaneous conversions of reduced and oxidized forms of nitrogen to gaseous products by pure cultures (referenced examples following).
Nitrifying microorganisms in particular have proven to be more versatile than previously thought and much remains to be understood concerning their metabolic capabilities. ${ }^{3)}$

Remde and Conrad ${ }^{4}$ observed that Nitrosomonas europaea produced nitric oxide (NO) and nitrous oxide $\left(\mathrm{N}_{2} \mathrm{O}\right)$ while simultaneously utilizing ammonium $\left(\mathrm{NH}_{4}{ }^{+}\right)$ and nitrite $\left(\mathrm{NO}_{2}{ }^{-}\right)$. Chlorite, a denitrification inhibitor, stopped the production of these nitrogen gasses. Furthermore, when hydrazine $\left(\mathrm{N}_{2} \mathrm{H}_{4}\right)$, from which $\mathrm{NO}$ is not produced, was used in place of $\mathrm{NH}_{4}{ }^{+}$, production of $\mathrm{NO}$ and $\mathrm{N}_{2} \mathrm{O}$ was not reduced. Thus it was demonstrated that only $\mathrm{NO}_{2}{ }^{-}$ was donating nitrogen to gas production and intermediates in the nitrification pathway 
were not contributing. Production of $\mathrm{N}_{2} \mathrm{O}$ was greatest under anaerobic and oxygen-limiting conditions and was only a minor product under aerobic conditions. NO production, however, was relatively insensitive to dioxygen $\left(\mathrm{O}_{2}\right)$ levels; NO reductase activity thus appeared to be the more sensitive to $\mathrm{O}_{2}$.

Brock et al. ${ }^{5)}$ observed that $N$. europaea under $\mathrm{O}_{2}$ limitation $(<0.4 \mathrm{mg} / l)$ could oxidize $\mathrm{NH}_{4}{ }^{+}$and reduce $\mathrm{NO}_{2}{ }^{-}$at the same time evidently with both $\mathrm{O}_{2}$ and $\mathrm{NO}_{2}{ }^{-}$ serving as electron acceptors. Also, in suffocated anaerobic culture, equimolar losses of $\mathrm{NH}_{4}{ }^{+}$and $\mathrm{NO}_{2}{ }^{-}$occurred when $\mathrm{O}_{2}$ was considered absent. Furthermore, under low redox conditions $N$. eutropha demonstrated cell growth and denitrification activity utilizing hydrogen as an electron donor with $\mathrm{NO}_{2}{ }^{-}$as the only electron acceptor while $\mathrm{NH}_{4}{ }^{+}$, though present, was not used. Without molecular hydrogen, $\mathrm{NH}_{4}{ }^{+}$served as a suitable electron donor for $\mathrm{NO}_{2}{ }^{-}$ reduction for $N$. eutropha both in pure culture and in mixed culture with Enterobacter aerogenes under anoxic conditions in an organic media. Interestingly, with $E$. aerogenes present the equimolar reductions of $\mathrm{NH}_{4}{ }^{+}$and $\mathrm{NO}_{2}{ }^{-}$were enhanced over that of the pure $N$. eutropha culture. E. aerogenes (an chemoorganotroph) is not known to use $\mathrm{NH}_{4}{ }^{+}$and $\mathrm{NO}_{2}{ }^{-}$, thus it appears that it somehow stimulated the use of these substrates by $N$. eutropha. Escherichia coli and Serratia marcescens when used in place of $E$. aerogenes demonstrated no such benefit. Electron micrographs revealed differences in the compositions of intra-cytoplasmic membranes of $\mathrm{NH}_{4}{ }^{+}$oxidizing bacteria adapted to $\mathrm{O}_{2}$-limitation versus those from well aerated environments possibly reflecting higher enzyme counts in the $\mathrm{O}_{2}$-stressed organisms. Poth $^{6)}$ isolated a Nitrosomonas sp. capable of producing dinitrogen $\left(\mathrm{N}_{2}\right)$ while converting $\mathrm{NH}_{4}{ }^{+}$and $\mathrm{NO}_{2}{ }^{-}$under $\mathrm{O}_{2}$-stressed conditions for the first time. $\mathrm{CO}_{2}$ provided assimilatory carbon and energy was obtained from oxidation of $\mathrm{NH}_{4}{ }^{+}$. Labeled nitrogen and kinetic considerations were used to demonstrate that $\mathrm{N}_{2}$ production was only from denitrification of $\mathrm{NO}_{2}{ }^{-}$and not a side reaction in the nitrification path. They emphasized the commonly held view that strict anaerobic conditions cannot support growth of nitrifying organisms because $\mathrm{O}_{2}$ is required for the initial conversion of $\mathrm{NH}_{4}{ }^{+}$to hydroxylamine $\left(\mathrm{NH}_{2} \mathrm{OH}\right)$. de Bruijn et $a l .,{ }^{7}$ however, reported production of $\mathrm{N}_{2} \mathrm{O}$ by $N$. europaea under anaerobic conditions with $\mathrm{NO}_{2}{ }^{-}$serving as an electron acceptor and either $\mathrm{NH}_{4}{ }^{+}$or $\mathrm{NH}_{2} \mathrm{OH}$ serving as the donor. While no growth was observed under anaerobic conditions, aerobic growth of $N$. europaea while oxidizing $\mathrm{NH}_{2} \mathrm{OH}$ (mixotrophically with $\mathrm{NH}_{4}{ }^{+}$) was demonstrated for the first time. Under these aerobic growth conditions, nitrogen loss to gaseous forms, evidently as a nitrification side product, were increased nearly an order of magnitude by use of the $\mathrm{NH}_{2} \mathrm{OH}$ substrate (perhaps involving a chemical reaction with $\mathrm{NO}_{2}{ }^{-}$).

Mulder et $a l .{ }^{8)}$ observed the disappearance of $\mathrm{NH}_{4}{ }^{+}$in a denitrifying fluidized bed reactor where both $\mathrm{NH}_{4}{ }^{+}$and nitrate $\left(\mathrm{NO}_{3}{ }^{-}\right)$consumption were correlated with an increase in gas production. This phenomena was further characterized by van de Graaf et $a l^{91}$ and confirmed to be a biological conversion. Anaerobic testing conditions were used to demonstrated that $\mathrm{O}_{2}$ was not involved. Labeled nitrogen was used to show that both $\mathrm{NH}_{4}{ }^{+}$and $\mathrm{NO}_{3}{ }^{-}$were donating to $\mathrm{N}_{2}$ formation in essentially equimolar amounts. These factors demonstrated the unlikelihood that known nitrifying bacteria were involved. Stoichiometric considerations suggested that 
$\mathrm{NO}_{2}{ }^{-}$was the direct oxidizing agent of $\mathrm{NH}_{4}{ }^{+}$in an energetically favorable exergonic reaction as per the following equation: ${ }^{10)}$

$$
\mathrm{NH}_{4}{ }^{+}+\mathrm{NO}_{2}{ }^{-} \longrightarrow \mathrm{N}_{2}+2 \mathrm{H}_{2} \mathrm{O}
$$

The anaerobic ammonium-oxidizing (Anammox) organisms were further studied in anautotrophic synthetic medium. ${ }^{11)} \mathrm{WithNH}_{4}{ }^{+}$ and $\mathrm{NO}_{2}{ }^{-}$supplied as the electron donor and acceptor, respectively, $\mathrm{N}_{2}$ was the main reaction product and incorporation of inorganic carbon was demonstrated. It is interesting that organic compounds were shown to be inhibitory to the process considering that the phenomena was first discovered in a denitrifying reactor with a substantial organic loading. Electron micrographs showed unusual, irregular shapes for the dominant organisms. Furthermore, an increase in the unique metabolic activity was correlated with an increase in ether lipids, cytochromes, and a red culture tint. Though preliminary, the observed lipid composition opens the possibility that archaeal microorganisms are involved. Strous et $a l .{ }^{12)}$ further elucidated that the Anammox process is reversibly inhibited by $\mathrm{O}_{2}$ and discussed its potential use in a nitrogen abatement process. An alternating aerobic-anaerobic treatment scheme could conceivably find a balance between generation of $\mathrm{NO}_{2}{ }^{-}$by conventional aerobic nitrification and its subsequent conversion to $\mathrm{N}_{2}$ via an interaction with $\mathrm{NH}_{4}{ }^{+}$ in an induced anaerobic phase-both phases occurring in a mutually autotrophic system.

Objectives The objective of this work was to investigate biological nitrogen transformations in environments where $\mathrm{O}_{2}$ and labile organic compounds are limiting or missing. These constraints were considered in order to probe less commonly considered phenomena for possible beneficial applications. Where cycling nitrogen from a reduced form $\left(\mathrm{NH}_{4}^{+}\right)$via an oxidized state $\left(\mathrm{NO}_{2}{ }^{-}\right.$or $\left.\mathrm{NO}_{3}{ }^{-}\right)$to a gaseous product (e.g., $\mathrm{N}_{2}$ ) is considered, environments lacking in $\mathrm{O}_{2}$ or organic compounds are at an obvious disadvantage. Pulsed chemical and energy inputs would be required. Such inputs are common for nitrogenous wastewater treatment facilities; however, where treatment is required for a drinking water source, addition of an organic substrate / contaminant is problematic if not risky. This investigation is envisioned to be a step in improving our understanding of nitrogen cycling capabilities and methods to enhance these phenomena in a remedial capacity.

These objectives were met by conducting batch assays with cultures acclimated to the proposed testing environment. $\mathrm{O}_{2}$-limiting / stressed conditions were initially used where cultivation of facultative organisms would be favorable. Oxidized forms of nitrogen $\left(\mathrm{NO}_{2}\right.$ or $\mathrm{NO}_{3}{ }^{-}$) were provided as potential electron acceptors and reduced nitrogen $\left(\mathrm{NH}_{4}{ }^{+}\right)$, as the intended electron donor. Inorganic carbon was supplied as to be non-limiting. Organic carbon was not supplied but its presence in trace quantities as cellular storage material or via endogenous decay is not excluded as a possibility. Frequent mixing was employed to reduce testing variables that can be contributed to gradients. Performance was evaluated by quantification of key aqueous components- $\mathrm{NH}_{4}^{+}, \mathrm{NO}_{2}{ }^{-}, \mathrm{NO}_{3}{ }^{-}, \mathrm{pH}$, and oxidation reduction potential (ORP).

\section{MATERIALS AND METHODS}

Initial batch assays were conducted in 1-liter or 0.5 -liter glass flasks ( $1.0 l$ or $0.4 l$ initial sample volumes) closed with rubber stoppers. Plastic syringe $(24 \mathrm{~m} l)$ attachments were used for pressure relief. For attachment connections either silicon or polyvinyl (PV) tubing (ca. $20 \mathrm{~cm}$ with $0.6 \mathrm{~cm}$ 
diameter) was used as noted. Subsequent jar assays were conducted in $250 \mathrm{~m} l$ or $100 \mathrm{ml}$ amber glass jars $(200 \mathrm{~m} l$ or $80 \mathrm{~m} l$ samples) with tight fitting plastic screw caps (with inner rubber cushion) or rubber stoppers. No attachments were used with jar assays.

Sludge used as culture seed came from two sources: an ongoing, in-house anoxic denitrifying batch reactor utilizing methanol as an organic substrate (ca. $0.2 \mathrm{~mm}$ diameter granular sludge) and an ongoing, in-house aerobic activated sludge reactor (flocculant sludge). Sludges were washed with tap and deionized water prior to use. Prepared culture solutions were purged in their respective containers (flasks or jars) with nitrogen gas for about 15 minutes. Jars were then evacuated and sealed in a positive pressure nitrogen glove-box. Sealed flasks and jars were incubated in the dark at $25{ }^{\circ} \mathrm{C}$ (outside of glove-box). Containers were opened for sampling only in the glove-box.

The reduced nitrogenous substrate was added as $\left(\mathrm{NH}_{4}\right)_{2} \mathrm{SO}_{4}$ or $\mathrm{NH}_{4} \mathrm{Cl}$; in oxidized form, $\mathrm{NaNO}_{3}$ or $\mathrm{NaNO}_{2}$ was used. An activated sludge nutrient solution was used for one initial assay (as noted in Results) and consisted of (per liter): $105 \mathrm{mg}$ $\mathrm{NaHCO}_{3}, 2.7 \mathrm{mg} \mathrm{KH} \mathrm{PO}_{4}, 5.0 \mathrm{mg} \mathrm{NaCl}, 7.0$ $\mathrm{mg} \mathrm{KCl}, 7.0 \mathrm{mg} \mathrm{CaCl}$, and $5.0 \mathrm{mg} \mathrm{MgSO}_{4}$. The nutrient solution for most assays (referred to herein as the standard type nutrient solution) consisted of (per liter) : 500

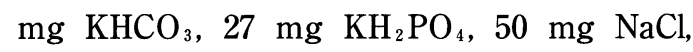
$70 \mathrm{mg} \mathrm{KCl}, 70 \mathrm{mg} \mathrm{CaCl}_{2}, 50 \mathrm{mg} \mathrm{MgSO}_{4}$, $9.0 \mathrm{mg} \quad \mathrm{FeSO}_{4} \cdot 7 \mathrm{H}_{2} \mathrm{O}$, and $1.0 \mathrm{ml}$ of micro-nutrient solution. The micro-nutrient solution consisted of (per liter): $0.25 \mathrm{~g}$ $\mathrm{CuSO}_{4} \cdot 5 \mathrm{H}_{2} \mathrm{O}, 0.43 \mathrm{~g} \mathrm{ZnSO}_{4} \cdot 7 \mathrm{H}_{2} \mathrm{O}, 0.24 \mathrm{~g}$ $\mathrm{CoCl}_{2} \cdot 6 \mathrm{H}_{2} \mathrm{O}, \quad 0.99 \mathrm{~g} \quad \mathrm{MnCl}_{2} \cdot 4 \mathrm{H}_{2} \mathrm{O}, \quad 0.22 \mathrm{~g}$ $\mathrm{Na}_{2} \mathrm{MoO}_{4} \cdot 2 \mathrm{H}_{2} \mathrm{O}, 0.19 \mathrm{~g} \mathrm{NiCl}_{2} \cdot 6 \mathrm{H}_{2} \mathrm{O}, 0.11 \mathrm{~g}$ $\mathrm{Na}_{2} \mathrm{SeO}_{4}$, and $0.014 \mathrm{~g} \mathrm{H}_{3} \mathrm{BO}_{3}$ (after van de Graaf et al., ${ }^{11)}$ ). Adjustments to $\mathrm{pH}$ were made with $1 \mathrm{~N} \mathrm{H}_{2} \mathrm{SO}_{4}$.
$\mathrm{NO}_{3}{ }^{-}$was determined by the UV spectrophotometricscreeningmethod and $\mathrm{NO}_{2}{ }^{-}$ by the colorimetric method. ${ }^{13)} \mathrm{NO}_{2}{ }^{-}$was found to give an absorbance response in the $\mathrm{NO}_{3}{ }^{-}$screening method equal to $25 \%$ of the $\mathrm{NO}_{3}{ }^{-}$response on an equal weight basis and corrections were appropriately made. $\mathrm{NH}_{4}{ }^{+}$ was determined by the phenate method (JIS, K0102 42). Oxidation reduction potential (ORP) was measured with a UK 2030 meter using a UC-702E (Pt) electrode (Central Kagaku, Kyoto), dissolved oxygen (DO) with a UC-12 Digital DO meter using a standard probe (Central Kagaku), and $\mathrm{pH}$ with a Mettler Toledo $320 \mathrm{pH}$ meter. For jar assays with rubber stoppers only, ORP (as above) and $\mathrm{pH}$ (with Duotest $\mathrm{pH}$ indicator paper, 0 . 3 unit accuracy; Macherey-Nagel GmbH \& Co., Duren, Germany) were measured in situ in the nitrogen glove-box. Total sludge concentrations were estimated as mixed liquor suspended solids (MLSS) and are reported as averages of duplicate assays. Sludge samples were washed twice (centrifuging at $3,000 \mathrm{~g}$ for 10 minutes) and dried at $105{ }^{\circ} \mathrm{C}$ ( 2 hours) to determine the MLSS component. Standard deviations (SD) were determined with respect to $n-1$ data.

Scanning electron microscopy (SEM) micrographs were taken with an electron microscope (JEOL JSM-5310LV, Nihon Denshi Co.). The sample was prepared as follows: A suspension containing approximately $25 \mathrm{mg}$ (dry weight) of sludge was centrifuged $(3,000 \mathrm{~g}$ for 5 minutes, typical) and decanted, washed five times (with vortex mixing, centrifuging and decanting) in $0.1 \mathrm{M}$ phosphate buffer $(\mathrm{pH}$ 7.4), hardened for 60 minutes in $2.5 \%$ glutaraldehyde (prepared in phosphate buffer), washed five times (as above), fixed for 30 minutes in $1.0 \% \mathrm{OsO}_{4}$ (in phosphate buffer), washed three times (as above), dewatered in $50 \%$ and $70 \%$ ethanol for 10 
minutes each (with centrifuging and decanting), stored in $90 \%$ ethanol overnight $\left(4{ }^{\circ} \mathrm{C}\right)$, then washed in t-butyl alcohol three times, dried on a critical point dryer (JEOL JFD-300), and coated with gold on an ion sputtering device (JEOL JFC-1100E).

\section{RESEARCH PROTOCOL}

Experiments were conducted in three phases. In Phase I, preliminary work focused on assessing responses of seed sludges from differing origins under $\mathrm{O}_{2}$ limiting or stressed conditions with no attempt to assure strict anaerobiosis (defined herein as $\mathrm{O}_{2}$ -stressed conditions). Phase II focused on employing stringency in $\mathrm{O}_{2}$ exclusion (anaerobic conditions). While $\mathrm{NO}_{2}{ }^{-}$was produced in Phase I assays and introduced in one Phase II test, its use as a substrate in place of $\mathrm{NO}_{3}{ }^{-}$was the focus of research in Phase III under anaerobic conditions.

Testing conditions used in Phase I are outlined in Table 1. Sludges of differing oxidation state origins (i.e., aerobic activated sludge and anoxic denitrifying sludge) were used in flasks with silicon tubing (not excluding limited transfusion of $\mathrm{O}_{2}$ ). The transition from A.1 to A.2 consisted of washing the sludge under ambient air and restocking with fresh substrates and nutrients as for the initiation of a new assay (as per Materials and Methods). The transition from B.1 to B.2 constituted of addition of supplemental components to the existing culture in the glove-box.

Testing conditions used in Phase II under anaerobic conditions are outlined in Table 2 . B.3 contained sludge of denitrifying origins that had been used in Phase I and was thus conditioned without an organic substrate for about four months. C.1, also containing sludge of denitrifying origins, had been cultured under autotrophic, $\mathrm{O}_{2}$-stressed conditions (flask with silicon tubing) for about two months prior to use in Phase II.

Testing conditions used in Phase III are outlined in Table 3. Anaerobic conditions (as in Phase II) were continued with $\mathrm{NO}_{2}{ }^{-}$ being supplied as the only intended electron acceptor. Assay C.2 contained sludge that had been used in Phase II. C.2 then served as the sludge source for all subsequent assays with C.2, C.3, and C.5 differing only in culture age. C.4 and C. 6 served as parallel inhibitory controls to C.3 and C.5, respectively.

Table 1 Conditions of assays in Phase I. All assays conducted in flask with silicon tubes. Solids and ORP data shown in Figure 1.

\begin{tabular}{|c|l|l|l|l|}
\hline Assay & \multicolumn{1}{|c|}{$\begin{array}{c}\text { Sludge } \\
\text { Source }\end{array}$} & $\begin{array}{c}\text { Nitrogen } \\
\text { Substrates }\end{array}$ & $\begin{array}{l}\text { Supplement } \\
\text { Nutrients }\end{array}$ & \multicolumn{1}{c|}{$\mathrm{pH}$} \\
\hline A.1 & $\begin{array}{l}\text { Activated } \\
\text { sludge }\end{array}$ & $\begin{array}{l}\left(\mathrm{NH}_{4}\right)_{2} \mathrm{SO}_{4} \\
\& \mathrm{NaNO}_{3}\end{array}$ & $\begin{array}{l}\text { Activated } \\
\text { sludge type }\end{array}$ & $\begin{array}{l}\text { 8.2 unadjusted } \\
(\mathrm{SD}, 0.37 ; \mathrm{n}, 21)\end{array}$ \\
\hline A.2 & A.1 & $\begin{array}{l}\left(\mathrm{NH}_{4}\right)_{2} \mathrm{SO}_{4} \\
\& \mathrm{NaNO}_{3}\end{array}$ & $\begin{array}{l}\text { Standard } \\
\text { type }\end{array}$ & $\begin{array}{l}7.1 \text { adjusted } \\
\text { (SD, 0.28; }, ~ 15)\end{array}$ \\
\hline B.1 & $\begin{array}{l}\text { Denitri. } \\
\text { sludge }\end{array}$ & $\begin{array}{l}\left(\mathrm{NH}_{4}\right)_{2} \mathrm{SO}_{4} \\
\& \mathrm{NaNO}_{3}\end{array}$ & $\begin{array}{l}\text { Standard } \\
\text { type }\end{array}$ & $\begin{array}{l}\text { 8.2 unadjusted } \\
\text { (SD, 0.18; n, 17) }\end{array}$ \\
\hline B.2 & B.1 c) $^{\mathrm{NH}_{4} \mathrm{Cl} \&}$ & $\begin{array}{l}\text { Standard } \\
\mathrm{NaNO}_{3}\end{array}$ & $\begin{array}{l}\text { 8.2 unadjusted } \\
\text { type }\end{array}$ \\
\hline
\end{tabular}

a) Adjusted only once at beginning of assay. ${ }^{b}$ Standard type nutrients without micro-nutrient addition (elsewhere micro-nutrients included with standard type). ${ }^{\text {c)}}$ Existing culture supplemented with substrates and micro nutrients; $\mathrm{SO}_{4}{ }^{2-}$ from $\left(\mathrm{NH}_{4}\right)_{2} \mathrm{SO}_{4}$ of B.1 remaining in solution. 
Table 2 Conditions of assays in Phase II. All assays conducted with $\mathrm{NH}_{4} \mathrm{Cl}$, standard nutrients, and unadjusted $\mathrm{pH}$.

\begin{tabular}{|c|l|l|l|l|}
\hline Assay & Sludge source & Approx. MLSS & \multicolumn{1}{|c|}{ Container } & \multicolumn{1}{|c|}{$\begin{array}{c}\text { Oxidized } \\
\text { N-substrate }\end{array}$} \\
\hline B.3 & B.2 ${ }^{\text {a) }}$ & $5 \mathrm{~g} l^{-1}$ & $\begin{array}{l}\text { Jar with } \\
\text { screw cap }\end{array}$ & $\begin{array}{l}\mathrm{NaNO}_{2} \\
\& \mathrm{NaNO}_{3} \text { b) }\end{array}$ \\
\hline C.1 & Denitri. sludge & $3 \mathrm{~g} l^{-1}$ & $\begin{array}{l}\text { Flask with } \\
\text { PV tubing }\end{array}$ & $\mathrm{NaNO}_{3}$ \\
\hline
\end{tabular}

${ }^{a}$ )Sludge from B.2 washed and stored under nitrogen gas (room

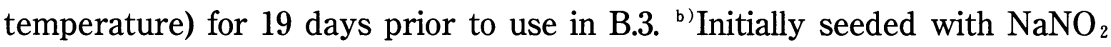
with subsequent additions of $\mathrm{NaNO}_{3}$.

Table 3 Conditions of assays in Phase III. All assays conducted with $\mathrm{NH}_{4}$ $\mathrm{Cl}$ and $\mathrm{NaNO}_{2}$ substrates and standard nutrients. Inhibitors, in C.4 and C.6, were used at $250 \mathrm{mg} /{ }^{-1}$.

\begin{tabular}{|c|c|c|c|c|}
\hline $\begin{array}{c}\text { Assay } \\
\text { (inhibitor) }\end{array}$ & $\begin{array}{l}\text { Sludge } \\
\text { source }\end{array}$ & $\begin{array}{l}\text { Approx. } \\
\text { MLSS }\end{array}$ & $\mathrm{pH}$ & $\mathrm{ORP}(\mathrm{mV})$ \\
\hline C. $2^{\mathrm{a})}$ & C.1 & $1.5 \mathrm{gl}^{-1}$ & $\begin{array}{l}7.2 \text { unadjusted } \\
\text { (end of assay) }\end{array}$ & 260 (end of assay) \\
\hline C. $3^{\mathrm{b})}$ & C. 2 & $5 \mathrm{gl}^{-1}$ & $\begin{array}{l}7.3 \text { adjusted }^{\mathrm{c})} \\
(\mathrm{SD}, 0.1 ; \mathrm{n}, 15)\end{array}$ & $266(\mathrm{SD}, 54 ; \mathrm{n}, 15)$ \\
\hline $\begin{array}{l}\text { C. } 4^{\mathrm{b})} \\
\left(\mathrm{HgCl}_{2}\right)\end{array}$ & C.2 & $5 \mathrm{gl}^{-1}$ & $\begin{array}{l}7.4 \text { adjusted }^{c)} \\
(\mathrm{SD}, 0 ; \mathrm{n}, 5)\end{array}$ & $130(\mathrm{SD}, 16 ; \mathrm{n}, 3)$ \\
\hline C. $5^{\mathrm{b})}$ & C. 3 & $5 \mathrm{gl}^{-1}$ & $\begin{array}{l}7.4 \text { adjusted }^{c)} \\
(\mathrm{SD}, 0 ; \mathrm{n}, 5)\end{array}$ & $201(\mathrm{SD}, 69 ; \mathrm{n}, 6)$ \\
\hline $\begin{array}{l}\text { C. } 6^{\text {b) }} \\
(\text { TCMP) })^{\text {d) }}\end{array}$ & C. 3 & $5 \mathrm{gl}^{-1}$ & $\begin{array}{l}7.4 \text { adjusted }{ }^{c)} \\
(\mathrm{SD}, 0 ; \mathrm{n}, 5)\end{array}$ & $226(\mathrm{SD}, 22 ; \mathrm{n}, 5)$ \\
\hline
\end{tabular}

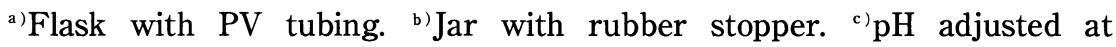
beginning of assay only. ${ }^{\mathrm{d})} 2$-chloro-6-(trichloromethyl)-pyridine.

\section{RESULTS}

Phase I For assay A.1, an initial decline in sludge solids (MLSS) and $\mathrm{NO}_{3}{ }^{-}$with an increase in $\mathrm{NH}_{4}{ }^{+}$occurred over the first 20 days (Figures 1 and 2). Evidently denitrification was occurring with organic compounds from storage or endogenous decay serving as electron donors with concurrent ammonification. Over the first 50 days, ORP gradually increased to a plateau of about $250 \mathrm{mV}$ (Figure 1). Also at about day 50 , the rate of $\mathrm{NO}_{3}{ }^{-}$disappearance declined and $\mathrm{NH}_{4}{ }^{+}$disappearance began with a accumulation of $\mathrm{NO}_{2}{ }^{-}$(Figure 2). Total nitrogen (total-N) disappearance rate was about $5 \mathrm{mg} \mathrm{N} l^{-1} \mathrm{~d}^{-1}$ during the course of A.1 when denitrification activity was dominant. During A.2, when $\mathrm{NO}_{3}{ }^{-}$reduction was greatly reduced and $\mathrm{NH}_{4}{ }^{+}$ disappearance (ca. $2 \mathrm{mg} \quad \mathrm{N} \quad l^{-1} \quad \mathrm{~d}^{-1}$ ) dominated, total- $\mathrm{N}$ disappeared at a rate of 3 $\operatorname{mg~N~} l^{-1} \mathrm{~d}^{-1}$.

B.1 also initially demonstrated apparent denitrification (Figure 3). Ammonification, however, was not evident and MLSS 


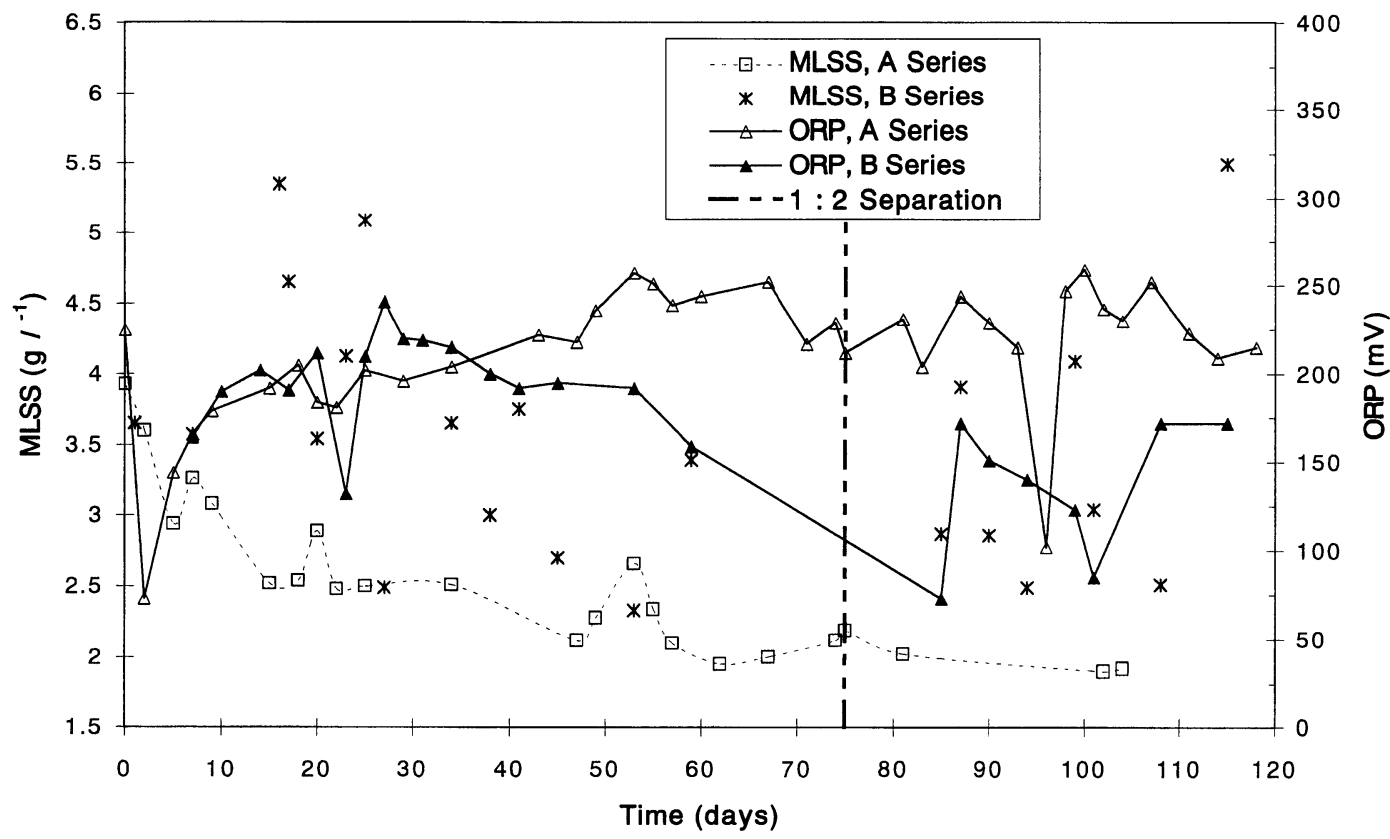

Fig. 1 Time course of MLSS and ORP for A and B series of Phase I (see Table 1). Vertical line at day 75 indicates separation of parts 1 and 2 of both series.

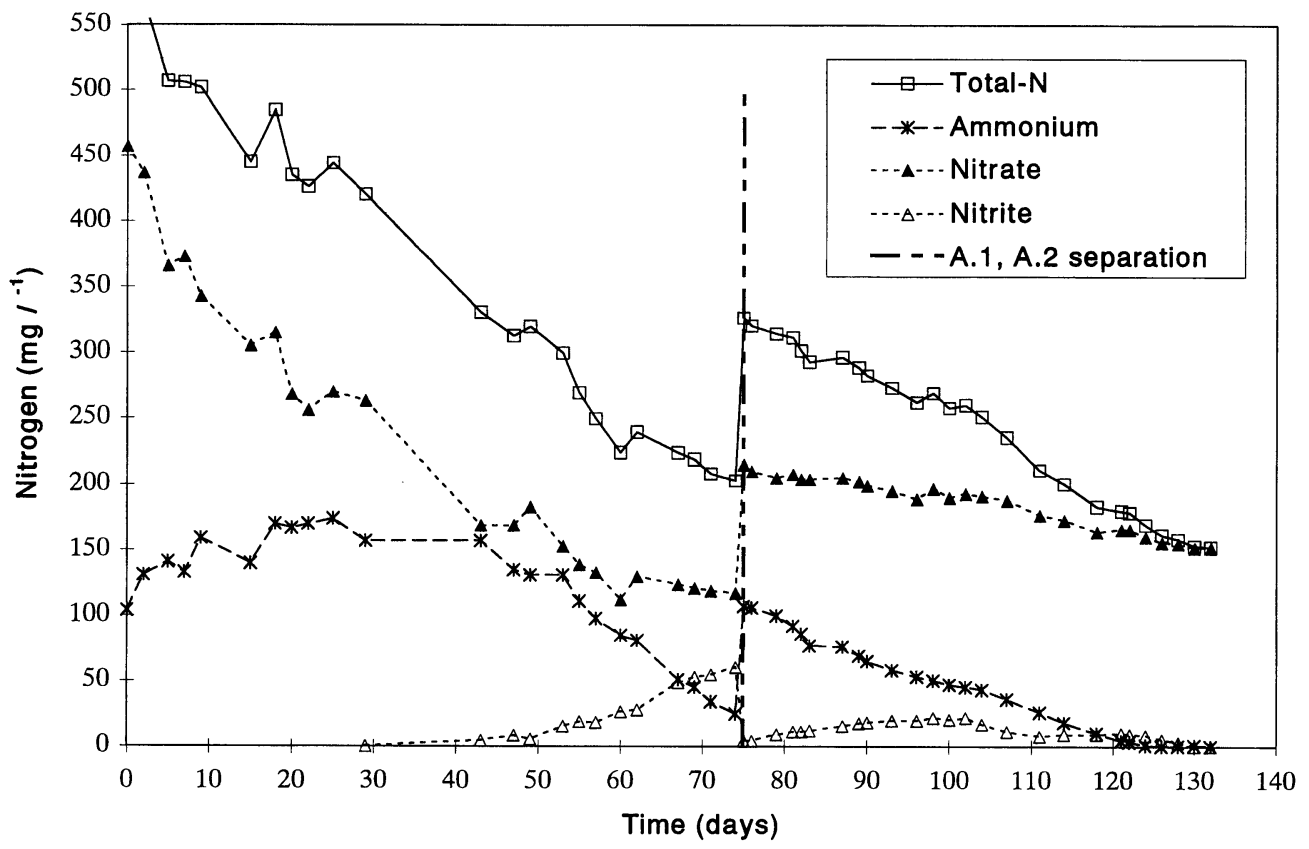

Fig. 2 Time course of nitrogen transformations for A.1 and A.2 assays of Phase I (see Table 1). Sludge washed and fresh substrates and nutrients introduced at transition from A.1 to A.2 (day 75 ). 
concentrations were widely scattered (the grainy textured sludge was difficult to sample in an even suspension due to rapid settling), thus no trends could be discerned (Figure 1). After only 20 days, B.1 experienced a significant reduction in $\mathrm{NO}_{3}{ }^{-}$ disappearance and an onset of $\mathrm{NH}_{4}{ }^{+}$ oxidation with accumulation of $\mathrm{NO}_{2}{ }^{-}$. This response was demonstrated repeatedly in $\mathrm{B}$. 2 (Figure 3). Over the course of B.1 and B. 2 during periods when $\mathrm{NH}_{4}{ }^{+}$disappearance ( 3 to $6 \mathrm{mg} \mathrm{N}^{-1} \mathrm{~d}^{-1}$ ) was the dominant form of nitrogen loss, total- $\mathrm{N}$ disappearance varied from about 2.5 to $5 \mathrm{mg} \mathrm{N} l^{-1} \mathrm{~d}^{-1}$.

Sulfate concentrations demonstrated no significant trends over the course of testing in all cases where used (data not shown). The use of sulfate in conjunction with a substrate was discontinued in subsequent assays (i.e., switch from $\left(\mathrm{NH}_{4}\right)_{2} \mathrm{SO}_{4}$ to $\mathrm{NH}_{4}$ $\mathrm{Cl})$, though still included as a supplemental nutrient.
Transfer of $\mathrm{O}_{2}$ through silicon tubing was assessed by rigging a flask with $1.0 l$ of tap water and otherwise treating the flask as per an ordinary assay. $\mathrm{O}_{2}$ intrusion was monitored by drawing samples and measuring DO in the glove-box. Over a 7-day period, a gradual declining rate of increase was observed (data not shown). The highest rate of transfer was estimated to be about $0.1 \mathrm{mg} \mathrm{O} \mathrm{O}_{2} \mathrm{l}^{-1} \mathrm{hr}^{-1}$ over the first 5 hours. Subsequently, two tests were conducted with $\mathrm{PV}$ tubing. In the first test, an increase of about $0.02 \mathrm{mg} \mathrm{O} \mathrm{O}_{2} l^{-1} \mathrm{hr}^{-1}$ was observed over the first 24 hours and $0.01 \mathrm{mg} \mathrm{O}_{2} \mathrm{l}^{-1} \mathrm{hr}^{-1}$ over the second 24 hours. In the second test, no intrusion was observed over 20 hours. Evidently, the rate of $\mathrm{O}_{2}$ intrusion can be reduced by an order of magnitude if not eliminated by use of PV material. The syringe apparatuses continually demonstrated pressure integrity precluding intrusion by channels other than the silicon matrix. $\mathrm{O}_{2}$

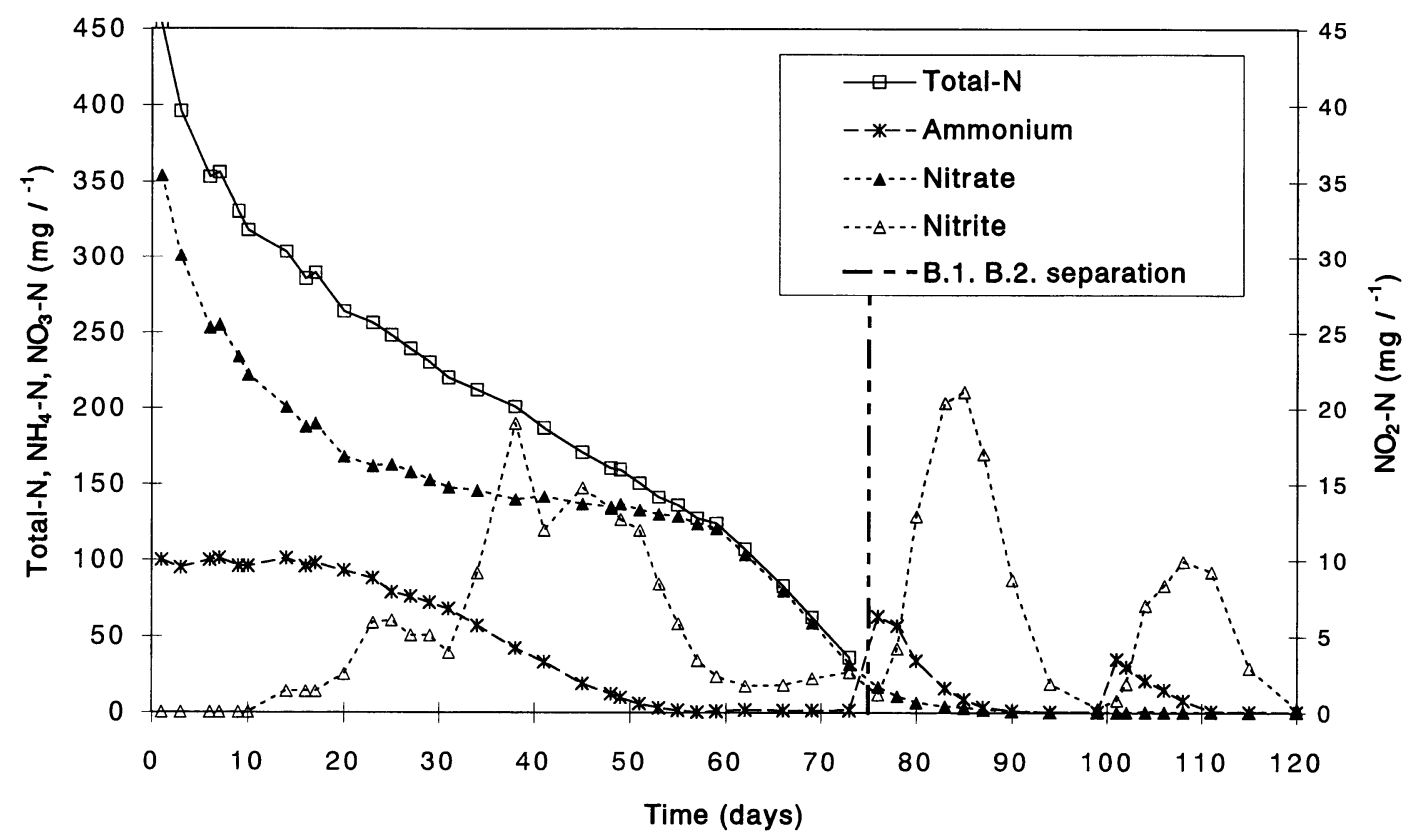

Fig. 3 Time course of nitrogen transformations for B.1 and B.2 assays of Phase I (see Table 1). Transition from B.1 to B.2 (day 75) consisted of chemical additions to the existing culture. Total-N not shown for B.2 (for clarity of other components). 
intrusion with a screw cap jar was also assessed. With storage in the glove-box, no $\mathrm{O}_{2}$ intrusion was detected over 48 hours (as expected). Furthermore, after transfer to storage in ambient air, no leakage was detected over 5 days.

Phase II Assay B.3 differed in its response from B.2 of which it originated. Over the first month when relatively low concentrations of $\mathrm{NO}_{2}{ }^{-}$ and $\mathrm{NO}_{3}{ }^{-}$were added, a gradual but consistent loss of $\mathrm{NH}_{4}{ }^{+}\left(0.6 \mathrm{mg} \mathrm{N} l^{-1} \mathrm{~d}^{-1}\right)$ occurred (Figure 4). The introduction of a relatively high concentration of $\mathrm{NO}_{3}{ }^{-}$(day 37) resulted in immediate, rapid $\mathrm{NO}_{3}{ }^{-}$loss with a gradual accumulation of $\mathrm{NH}_{4}{ }^{+}$. During the latter half of B.3 when $\mathrm{NH}_{4}{ }^{+}$ concentration demonstrated no significant changes, total- $\mathrm{N}$ disappearance rate was

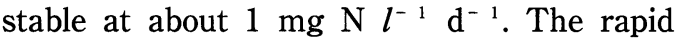
climb of $\mathrm{NO}_{2}{ }^{-}$with loss of $\mathrm{NH}_{4}{ }^{+}$following day 98 is attributed to traditional nitrification due to $\mathrm{O}_{2}$ intrusion during sampling (glove-box leak).

During assay C.1 (consisting of sludge of the same origins as the $\mathrm{B}$ series) a gradual accumulation of $\mathrm{NH}_{4}{ }^{+}$occurred over the first 40 days (Figure 5). Total-N losses were about $2 \mathrm{mg} \mathrm{N} l^{-1} \mathrm{~d}^{-1}$ and disappearance of $\mathrm{NH}_{4}{ }^{+}$ was not evidenced (not precluding the possibility of $\mathrm{NH}_{4}{ }^{+}$generation offsetting loss).

Phase III Apparently some $\mathrm{NO}_{3}{ }^{-}$had been carried over from C.1 into C.2 which was quickly reduced with the applied $\mathrm{NO}_{2}{ }^{-}$ (Figure 6). Subsequent additions of $\mathrm{NO}_{2}{ }^{-}$ were reduced at a lower rate (ca. $0.2 \mathrm{mg} \mathrm{N} l^{-1}$ $\mathrm{d}^{-1}$ ) which was about half that of the overall rate of $\mathrm{NH}_{4}{ }^{+}$loss $\left(0.55 \mathrm{mg} \mathrm{N} l^{-1} \mathrm{~d}^{-1}\right)$. Following the transfer to C.3, an initial increase in $\mathrm{NO}_{2}{ }^{-}$with a loss of $\mathrm{NH}_{4}{ }^{+}$ occurred (Figure 7). Evidently some $\mathrm{O}_{2}$ introduced during assay preparation had

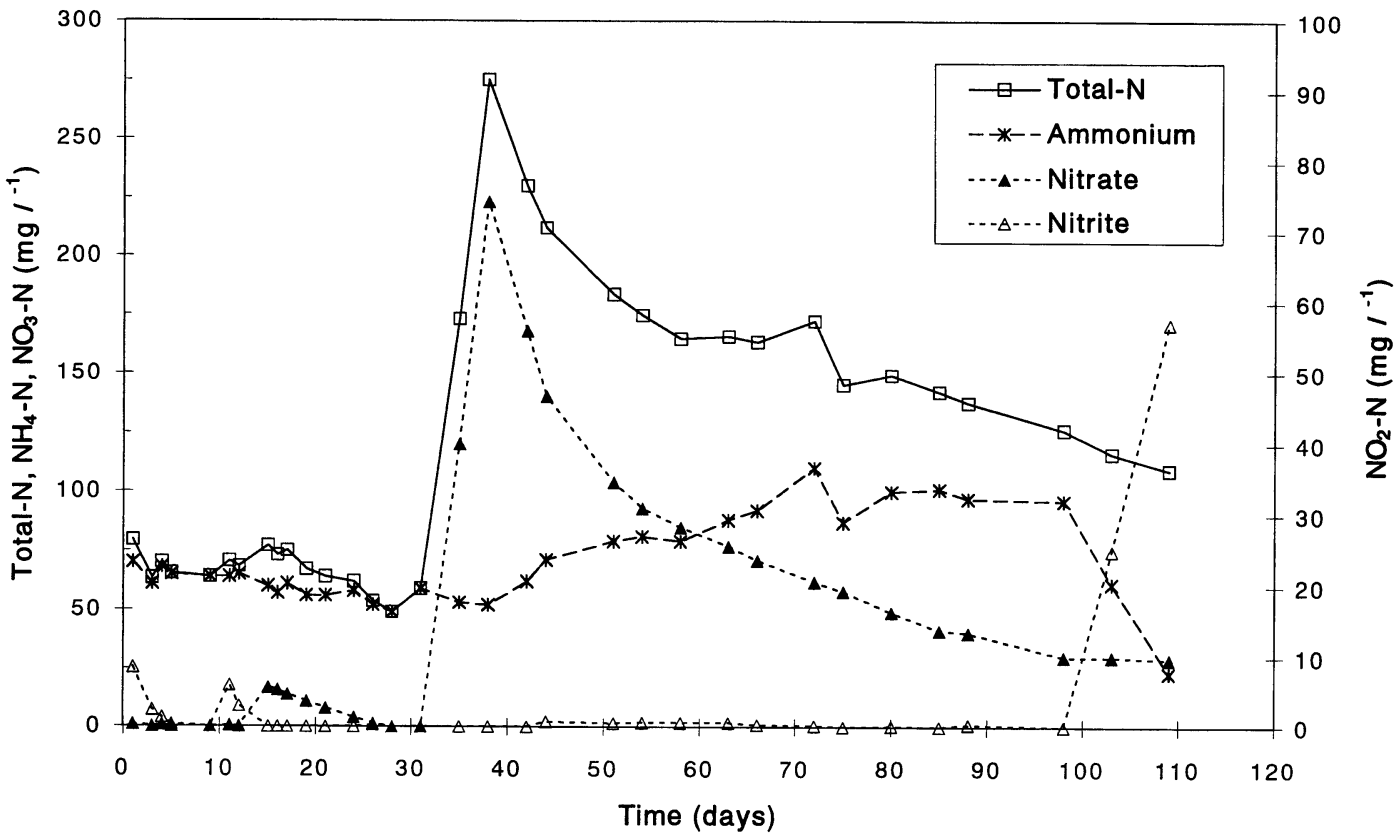

Fig. 4 Time course of nitrogen transformations for B.3 assay of Phase II (see Table 2). $\mathrm{NO}_{2}{ }^{-}$ substrate used at beginning (days 0 and 10 ) and $\mathrm{NO}_{3}{ }^{-}$subsequently added on days 14,33 , and $37 . \mathrm{O}_{2}$ intrusion occurred following day 98 (see text). 


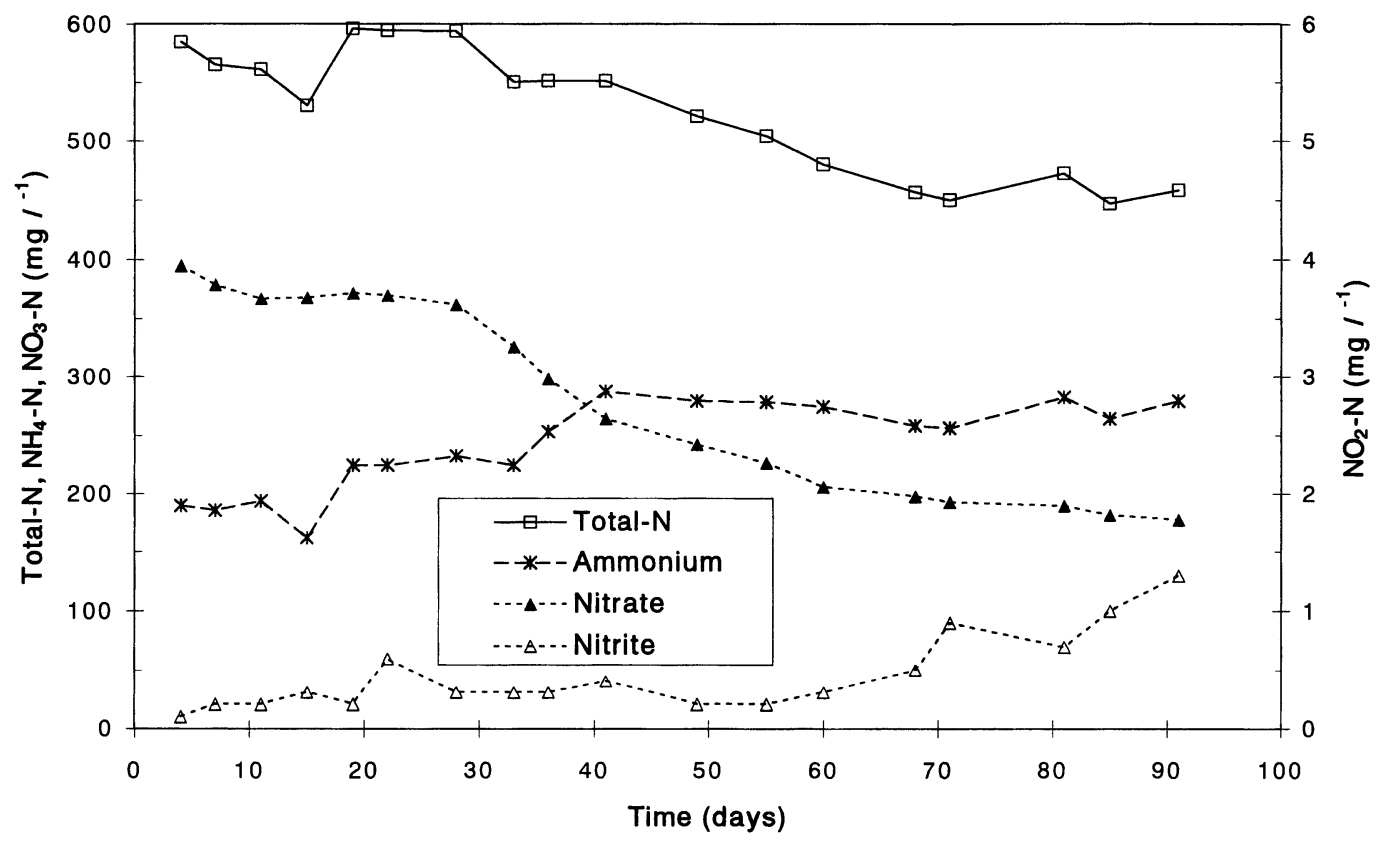

Fig. 5 Time course of nitrogen transformations for C.1 assay of Phase II (see Table 2).

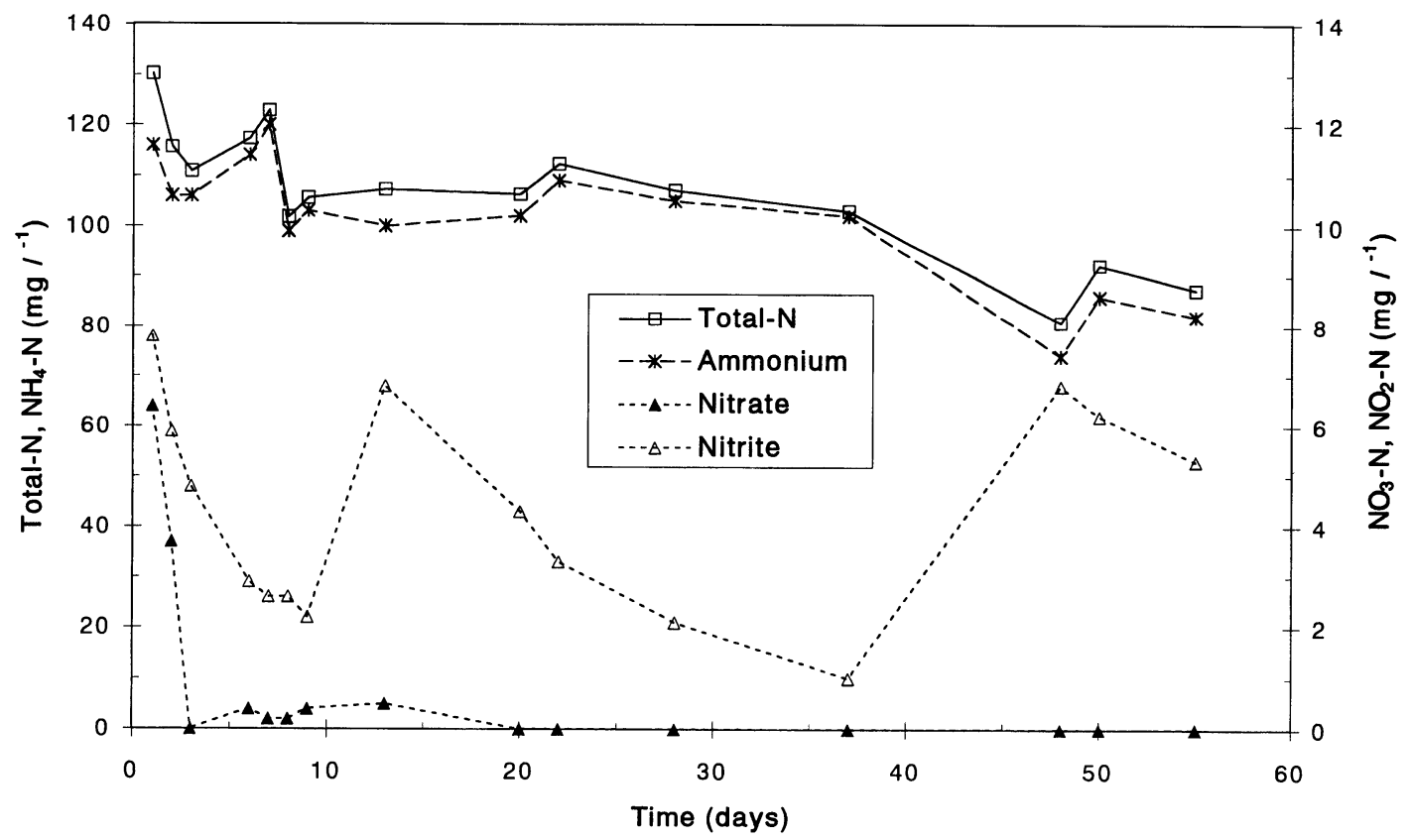

Fig. 6 Time course of nitrogen transformations for C.2 assay of Phase III (see Table 3). $\mathrm{NO}_{2}{ }^{-}$ substrate used from beginning and subsequently added on days 10 and 42 . 


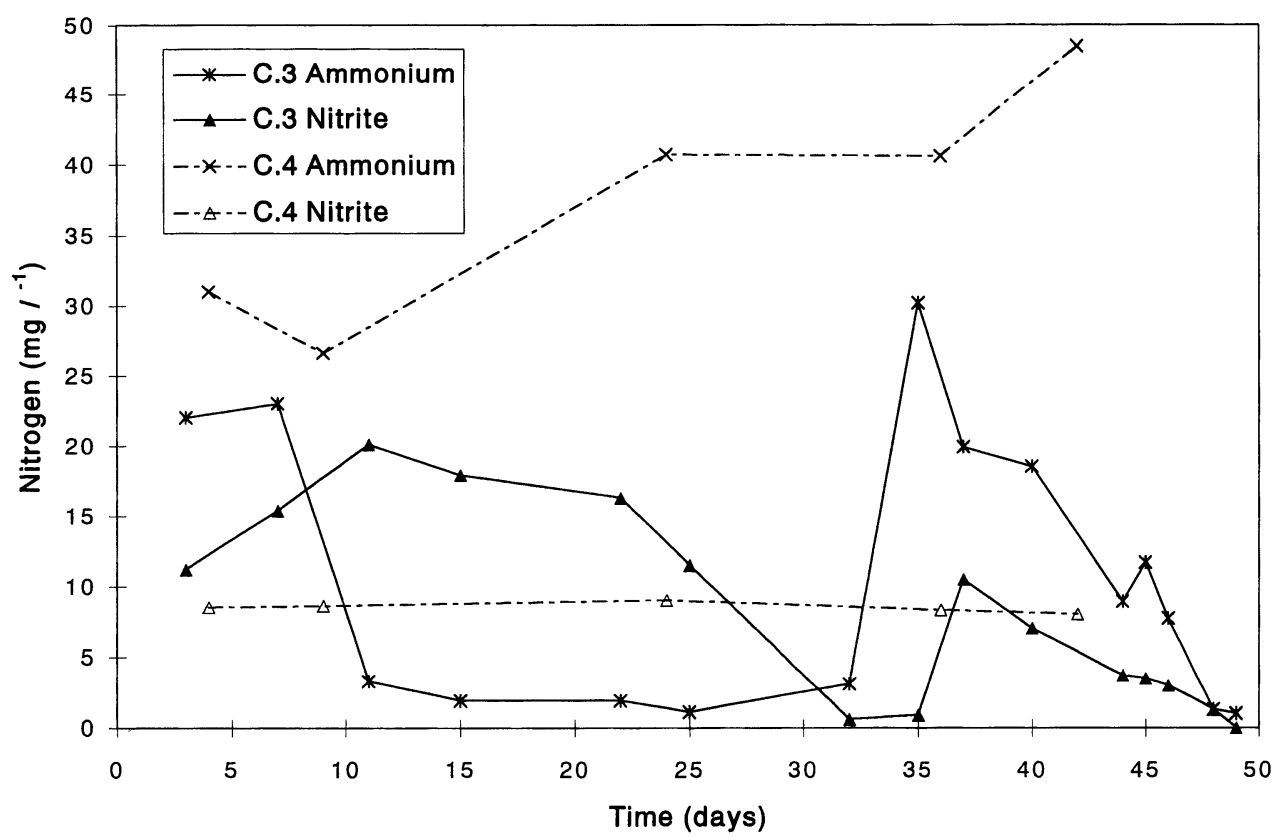

Fig. 7 Time course of nitrogen transformations for $\mathrm{C.3}$ and $\mathrm{C.} .4\left(\mathrm{HgCl}_{2}\right.$ control) assays of Phase III (see Table 3). For C.3, subsequent additions of $\mathrm{NH}_{4}{ }^{+}$and $\mathrm{NO}_{2}{ }^{-}$ substrates were made on days 34 and 36 , respectively.

persisted (inadequate purging) resulted in nitrification. Subsequent additions of $\mathrm{NH}_{4}{ }^{+}$ and $\mathrm{NO}_{2}{ }^{-}$were followed by disappearance rates of 1.7 and $0.8 \mathrm{mg} \mathrm{N} \quad l^{-1} \mathrm{~d}^{-1}$, respectively. In assays C.3, C.4, C.5, and C.6, $\mathrm{NO}_{3}{ }^{-}$with few exceptions was not detected (maximum occurrence of ca. $0.5 \mathrm{mg} \mathrm{N} l^{-1}$ ).

In assay C.4, $\mathrm{NO}_{2}{ }^{-}$transformations were arrested by the $\mathrm{HgCl}_{2}$ addition (Figure 7). $\mathrm{NH}_{4}{ }^{+}$, however, increased. The $\mathrm{HgCl}_{2}$ addition (250 $\mathrm{mg} \mathrm{l}^{-1}$ ), which was intended to terminate all microbial activity, may have been inadequate for the $5 \mathrm{~g}^{-1}$ sludge concentration allowing for some heterotrophs to persist. This or a chemical reaction may have lead to an oxidative release of $\mathrm{NH}_{4}{ }^{+}$.

In assay C.5 there was an immediate, steady disappearance of $\mathrm{NO}_{2}{ }^{-}$from the onset (Figure 8). Over the final nine-days, the disappearance rate of $\mathrm{NH}_{4}{ }^{+}\left(1.4 \mathrm{mg} \mathrm{N} l^{-1}\right.$ $\left.\mathrm{d}^{-1}\right)$ was about half that of $\mathrm{NO}_{2}^{-}\left(2.7 \mathrm{mg} \mathrm{N} l^{-1}\right.$ $\left.\mathrm{d}^{-1}\right)$. TCMP, used in C.6, is a nitrification inhibitor that prevents the oxidation of $\mathrm{NH}_{4}{ }^{+}$to hydroxylamine $\left(\mathrm{NH}_{2} \mathrm{OH}\right)$. In C.6, $\mathrm{NO}_{2}{ }^{-}$disappearance matched that of C.5 (without TCMP) but $\mathrm{NH}_{4}{ }^{+}$gradually accumulated (Figure 8).

An SEM micrograph of organisms from the C.5 assay is shown in Figure 9. Most organisms were elongated and less than 1.0 $\mu \mathrm{m}$ in length. Unusual morphologies, i.e., crescent or jagged bends in cell surfaces, were common. The culture was extremely filamentous and attachment of long tail-like appendages to cells was frequently evident. A few tightly packed clusters of cocci organisms (ca. $0.5 \mu \mathrm{m}$ diameter) were also evident (not shown).

\section{DISCUSSION}

The source of seed sludge clearly made a difference in the initial acclimation periods 


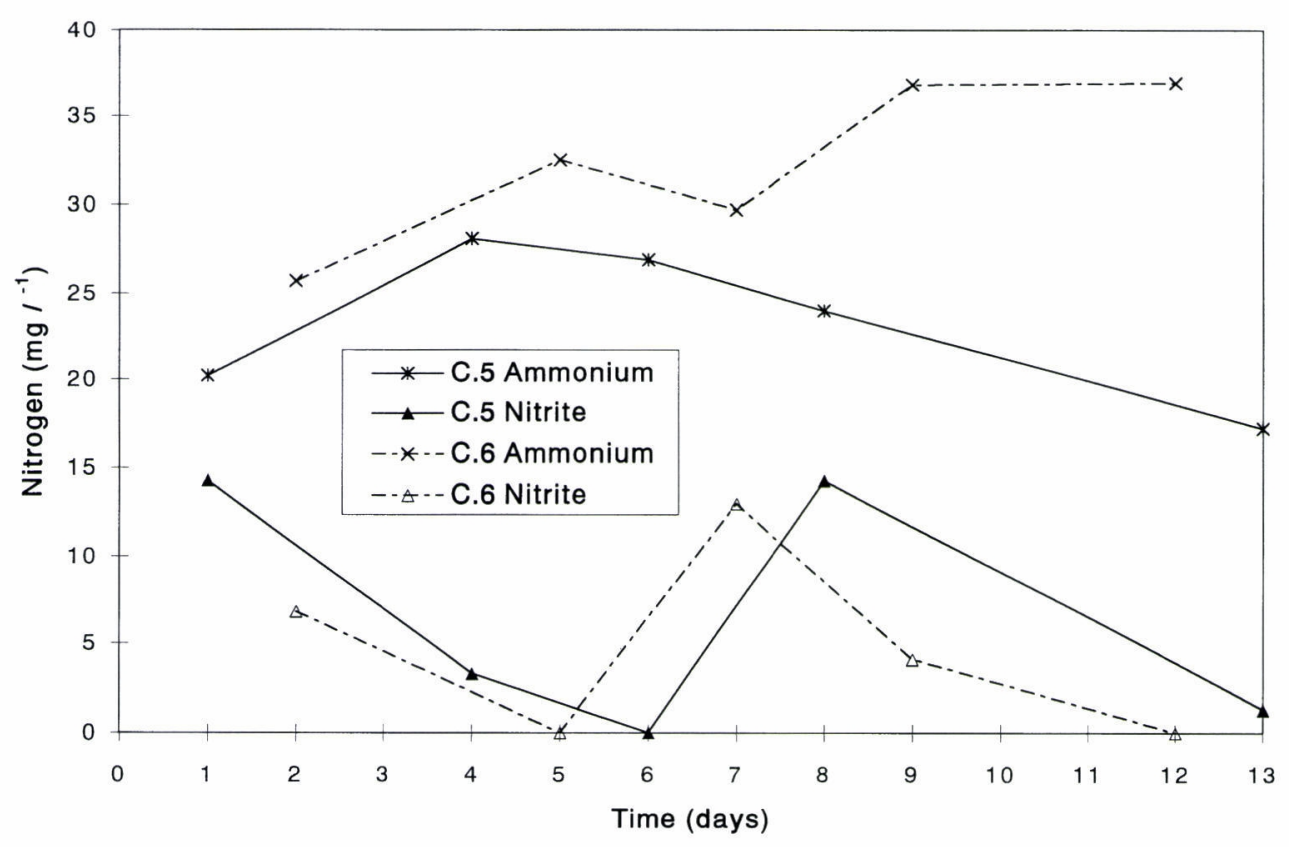

Fig. 8 Time course of nitrogen transformations for C.5 and C.6 (TCMP control) assays of Phase III (see Table 3). Subsequent additions of $\mathrm{NO}_{2}{ }^{-}$substrate were made on days 6 and 7 for C.6 and C.5, respectively.

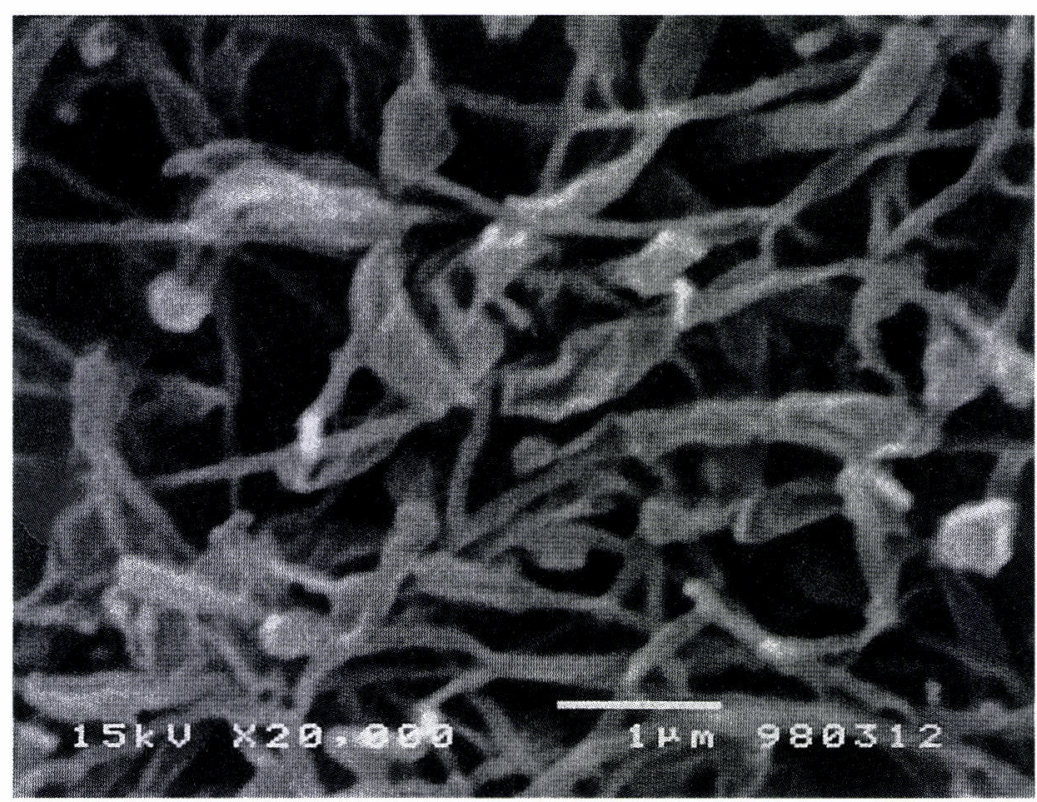

Fig. 9 Scanning electron micrograph of sample from C.5 at end of assay. Bar is $1.0 \mu \mathrm{m}$. 
when denitrification was apparent. Ammonification was evident in A.1 (of activated sludge origins, Figure 2) but not in B.1 (of denitrifying origins, Figure 3). Furthermore, the initial period of rapid $\mathrm{NO}_{3}{ }^{-}$decline in $\mathrm{B} .1$ was about half as long as that of A.1 (20 versus 40 days). That this initial reduction of $\mathrm{NO}_{3}{ }^{-}$in A.1 was traditional denitrification is supported by the concurrent decline in MLSS (Figure 1) and the increase in $\mathrm{NH}_{4}{ }^{+}$(ammonification), both indicative of an endogenous source of organic substrate. In B.1, carry over trace/storage organic materials with the source sludge may have been utilized.

In both the $\mathrm{A}$ and $\mathrm{B}$ series of Phase $\mathrm{I}$, a decline in the rate of $\mathrm{NO}_{3}{ }^{-}$reduction was associated with an onset of $\mathrm{NH}_{4}{ }^{+}$ disappearance and the appearance of $\mathrm{NO}_{2}{ }^{-}$. Furthermore, in B.1 the subsequent reduction in the $\mathrm{NH}_{4}{ }^{+}$disappearance rate and concentration (to near depletion) was followed by a restoration of the previous $\mathrm{NO}_{3}-$ disappearance rate (Figure 3). While the use of storage or trace organic materials to support denitrification during the first 20 days of $\mathrm{B} .1$ is plausible, after 60 days of incubation this explanation becomes tenuous and the possibility of alternate electron donors merits consideration.

The observed pattern of $\mathrm{NO}_{2}$ appearance continued in B.2 even after $\mathrm{NO}_{3}{ }^{-}$was allowed to expire (Figure 3). If the observed $\mathrm{NO}_{2}{ }^{-}$production was due to traditional nitrification, it is interesting that the organisms (or conditions) for $\mathrm{NO}_{2}{ }^{-}$ oxidation to $\mathrm{NO}_{3}{ }^{-}$were missing (or inadequate). Thus the previously noted reduction in the rate of $\mathrm{NO}_{3}{ }^{-}$disappearance was probably not due to an offset from $\mathrm{NO}_{2}{ }^{-}$oxidation to $\mathrm{NO}_{3}{ }^{-}$. The occurrence of nitrification terminating in $\mathrm{NO}_{2}{ }^{-}$was seen by Strous et $a l^{12)}$ when $\mathrm{O}_{2}$ was introduced to an anaerobic $\mathrm{NH}_{4}{ }^{+}$-oxidizing culture. Gas transfusion through silicon tubing (used in Phase I) could have provided an $\mathrm{O}_{2}$ source for nitrification. However, the maximum intrusion rate of $0.1 \mathrm{mg} \mathrm{O} \mathrm{O}^{-1} \mathrm{hr}^{-1}$ is nearly an order of magnitude lower than the theoretical $\mathrm{O}_{2}$ demand for conversion of $\mathrm{NH}_{4}{ }^{+}$to $\mathrm{NO}_{2}{ }^{-}$at the highest rate observed in the $\mathrm{B}$ series (i.e., $0.86 \mathrm{mg} \mathrm{O} \mathrm{O}_{2} \mathrm{l}^{-1} \mathrm{hr}^{-1}$ required for oxidation $0.25 \mathrm{mg} \mathrm{NH}{ }_{4}^{+} \mathrm{N}^{-1}$ $\mathrm{hr}^{-1}$ ). Pure cultures of $\mathrm{N}$. europaea have been observed to simultaneously utilize both $\mathrm{NH}_{4}{ }^{+}$and $\mathrm{NO}_{2}{ }^{-}$under various redox conditions. ${ }^{4,5,14)}$ Production of $\mathrm{NO}_{2}{ }^{-}$from oxidation of $\mathrm{NH}_{4}{ }^{+}$and its reduction, again utilizing $\mathrm{NH}_{4}{ }^{+4)}$ or hydrogen ${ }^{5)}$ as a reductant could be a contributing factor to transformations in B.2 (Figure 3) under $\mathrm{O}_{2}$ -stressed conditions. Similar transformations were observed with the activated sludge culture though at lower rates (A.2, Figure 2).

Expanding on the idea that $\mathrm{NO}_{2}^{-}$may serve to oxidize $\mathrm{NH}_{4}{ }^{+}$to $\mathrm{NO}_{2}{ }^{-}, \mathrm{NO}_{2}{ }^{-}$was supplied in place of $\mathrm{NO}_{3}{ }^{-}$as a substrate at the beginning of assay B.3 under anaerobic conditions (Phase II). Though containing sludge from B.2 (Phase I), the previous pronounced $\mathrm{NH}_{4}{ }^{+}$disappearance with $\mathrm{NO}_{2}{ }^{-}$ accumulation was not reproduced (Figure 4). Over the first month, though, when relatively low concentrations of $\mathrm{NO}_{2}{ }^{-}$and, subsequently, $\mathrm{NO}_{3}{ }^{-}$were added a gradual but consistent loss of $\mathrm{NH}_{4}{ }^{+}$occurred; however, the subsequent addition of a high concentration of $\mathrm{NO}_{3}{ }^{-}$(over $250 \mathrm{mg} l^{-1}$ ) resulted in a gradual accumulation of $\mathrm{NH}_{4}{ }^{+}$. Though speculative, $\mathrm{NH}_{4}{ }^{+}$oxidizing populations may have been overtaken and dissimilatory reduction of oxidized forms of nitrogen to $\mathrm{NH}_{4}{ }^{+}$may have contributed to the observed accumulation. ${ }^{15)}$ The immediate drop in $\mathrm{NH}_{4}{ }^{+}$with production of $\mathrm{NO}_{2}{ }^{-}$in response to $\mathrm{O}_{2}$ intrusion following day 98 demonstrated the versatility of the $\mathrm{NH}_{4}{ }^{+}$ 
-oxidizing organisms. It appears these organisms do not require an extended lag period to adapt or switch enzyme systems as observed by Bodelier et al. ${ }^{16)}$ for nitrifying organisms of an anoxic environment.

The transformations in C.1 utilizing $\mathrm{NH}_{4}{ }^{+}$ and $\mathrm{NO}_{3}{ }^{-}$substrates (Figure 5) follow similar patterns to those of the latter half of B.3 (both of Phase II). The sludge in C.1 (of denitrifying origins) was carried over into C.2 (Phase III) and used to more closely access transformations associated with the use of $\mathrm{NO}_{2}^{-}$as the oxidized nitrogen substrate. The mutual reductions of $\mathrm{NH}_{4}{ }^{+}$ and $\mathrm{NO}_{2}$ - observed over the first month of B.3 were again observed (at similar rates) in C.2 (Figure 6). The continuation into C.3 and ultimately C.5 demonstrated the reproducibility of these simultaneous conversions of $\mathrm{NH}_{4}{ }^{+}$and $\mathrm{NO}_{2}{ }^{-}$(latter parts of Figures 7 and 8, respectively). TCMP stopped the disappearance of $\mathrm{NH}_{4}{ }^{+}$and had no effect on $\mathrm{NO}_{2}{ }^{-}$conversion (C.6, Figure 8). Thus it appears that $\mathrm{NH}_{4}{ }^{+}$was not serving as an electron donor for $\mathrm{NO}_{2}{ }^{-}$ reduction under anaerobic conditions. These results differ from those of the anaerobic $\mathrm{NH}_{4}{ }^{+}$-oxidizing culture of Mulder et al. $;^{8)}$ however, the SEM micrographs (Figure 9) of organisms in the final assay bear a resemblance to the irregularly shaped organisms in that work ${ }^{11}$ yet differing in their filamentous nature.

In this screening effort, a gradual disappearance rate for $\mathrm{NH}_{4}{ }^{+}\left(0.55 \mathrm{mg} \mathrm{N} l^{-1}\right.$ $\left.\mathrm{d}^{-1}\right)$ concurrent with $\mathrm{NO}_{2}{ }^{-}$reduction $(0.2 \mathrm{mg}$ $\mathrm{N} l^{-1} \mathrm{~d}^{-1}$ ) occurred after about 5 months of incubation. An additional two months were required to achieve the maximum observed $\mathrm{NH}_{4}{ }^{+}$removal rate of $1.7 \mathrm{mg} \mathrm{N} l^{-1} \mathrm{~d}^{-1}$ $\left(\mathrm{NO}_{2}{ }^{-}\right.$reduction rate, $\left.0.8 \mathrm{mg} \mathrm{N} l^{-1} \mathrm{~d}^{-1}\right)$. Further inquiry is needed to determine if these phenomena can be optimized for inclusion in a remediation system. $\mathrm{O}_{2}$ levels and ORP control are key factors. Strict anaerobic conditions would be difficult to sustain in a commercial scale unit process without an organic substrate. Creating the conditions that allow for combining (or overlapping) nitrification and denitrification processes appear feasible and has been of interest in recent years. ${ }^{1,12}$

In natural environments the stressed conditions that could support the unique nitrogen transformations hereto discussed may be common. In this arena, however, our inquiry should focus not only on in situ remedial benefits but also on the potential environmental dangers. In both natural and engineered environments, stressed conditions are associated with nitrogen conversions terminating in $\mathrm{N}_{2} \mathrm{O}$, contributing to acid rain, greenhouse effect, and ozone depletion. ${ }^{1,17)}$ Accordingly, nitrogen remedial schemes cannot stop at unique solutions to water treatment problems-accountability of ultimate conversion products to a safe form such as $\mathrm{N}_{2}$ is essential.

\section{SUMMARY}

Biological transformation assays of soluble forms of inorganic nitrogen in autotrophic media under anaerobic and $\mathrm{O}_{2}$-stressed conditions revealed the following:

*During initial acclimation periods, cultures with seed sludge of denitrifying origins adapted quicker to the $\mathrm{O}_{2}$-stressed, autotrophic testing environment than those of activated sludge origins.

"Under $\mathrm{O}_{2}$-stressed conditions a decline in the rate of $\mathrm{NO}_{3}{ }^{-}$reduction was associated with an onset of $\mathrm{NH}_{4}{ }^{+}$disappearance. The estimated rate of $\mathrm{O}_{2}$ intrusion, however, was not sufficient to account for the $\mathrm{NH}_{4}{ }^{+}$ transformation and $\mathrm{NO}_{2}^{-}$was not being oxidized to $\mathrm{NO}_{3}{ }^{-}$. Near depletion of $\mathrm{NH}_{4}{ }^{+}$ resulted in a restoration of $\mathrm{NO}_{3}{ }^{-}$reduction where an organic electron donor was not 
considered present.

*Under anaerobic conditions $\left(\mathrm{O}_{2}\right.$ exclusion) use of low levels of $\mathrm{NO}_{2}{ }^{-}$and $\mathrm{NO}_{3}{ }^{-}(<15$ $\left.\mathrm{mgl} l^{-1}\right)$ as substrates were associated with a gradual disappearance of $\mathrm{NH}_{4}{ }^{+}$which was inhibited by relatively high concentrations of $\mathrm{NO}_{3}{ }^{-}$.

${ }^{*}$ Using $\mathrm{NO}_{2}{ }^{-}$as a potential electron acceptor, concurrent disappearances of $\mathrm{NO}_{2}{ }^{-}$and $\mathrm{NH}_{4}{ }^{+}$occurred. These reproducible conversions, however, were not mutual; i.e., termination of $\mathrm{NH}_{4}{ }^{+}$oxidation did not stop $\mathrm{NO}_{2}{ }^{-}$reduction. SEM micrographs showed a dominance of irregularly shaped microorganisms.

\section{REFERENCES}

1 ) Kuenen, J. G., and Robertson, L. A. : Combined nitrification-denitrification processes. FEMS Microbiology Reviews 15 : 109-117 (1994).

2 ) Robertson, L. A., Dalsgaard, T., Revsbech, N.-P., and Kuenen, J. G. : Confirmation of 'aerobic denitrification' in batch cultures, using gas chromatography and ${ }^{15} \mathrm{~N}$ mass spectrometry. FEMS Microbiology Ecology 18:113-120 (1995).

3 ) Abeliovich, A.: Transformations of ammonia and the environmental impact of nitrifying bacteria. Biodegradation 3 : 255-264 (1992).

4 ) Remde, A., and Conrad, R. : Production of nitric oxide in Nitrosomonas europaea by reduction of nitrite. Arch. Microbiol. 154: 187-191 (1990).

5 ) Brock, E., Schmidt, I., Stuven, R., and Zart, D. : Nitrogen loss caused by denitrifying Nitrosomonas cells using ammonium or hydrogen as electron donors and nitrite as electron acceptor. Arch. Microbiol. 163 : 16-20 (1995).

6 ) Poth, M.: Dinitrogen production from nitrite by a Nitrosomonas Isolate. Appl. Environ. Microbiol. 52: 957-959 (1986).
7 ) de Bruijn, P., van de Graaf, A. A., Jetten, M. S. M., Robertson, L. A., and Kuenen, J. G.: Growth of Nitrosomonas europaea on hydroxylamine. FEMS Microbiology Letters 125: 179-184 (1995).

8 ) Mulder, A., van de Graaf, A. A., Robertson L. A., and Kuenen, J. G. : Anaerobic ammonium oxidation discovered in a denitrifying fluidized bed reactor. FEMS Microbiology Ecology 16: 177-184 (1995).

9 ) van de Graaf, A. A., Mulder, A., de Bruijn, P., Jetten, M. S. M., Robertson, L. A., and Kuenen, J. G.: Anaerobic oxidation of ammonium is a biologically mediated process. Appl. Environ. Microbiol. 61: 1246-1251 (1995).

10) Broda, E. : Two kinds of lithotrophs missing in nature. Z. fur Allg. Mikrobiol. 17 : 491-493 (1977).

11) van de Graaf, A. A., de Bruijn, P., Robertson, L. A., Jetten M. S. M., and Kuenen, J. G.: Autotrophic growth of anaerobic ammonium-oxidizing micro-organisms in a fluidized bed reactor. Microbiology 142: 2187-2196 (1996).

12) Strous, M., van Gerven, E., Kuenen, J. G., and Jetten, M. : Effects of aerobic and microaerobic conditions on anaerobic ammonium-oxidizing (Anammox) sludge. Appl. Environ. Microbiol. 63: 2446-2448 (1997).

13) APHA, AWWA and WEF : Standard Methods for the Examination of Water and Wastewater, 19th edition. American Public Health Association, Washington DC (1995).

14) Abeliovich, A., and Vonshak, A. : Anaerobic metabolism of Nitrosomonas europaea. Arch. Microbiol. 158: 267-270 (1992).

15) Knowles, R.: Denitrification. Microbiological Reviews 46: 43-70 
(1982).

16) Bodelier, P. L. E., Libochant, J. A., Blom, C. W. P. M., and Laanbroek, H. J. : Dynamics of nitrification and denitrification in root-oxygenated sediments and adaptation of ammonia-oxidizing bacteria to low-oxygen or anoxic habitats. Appl. Environ. Microbiol. 62: 4100-4107 (1996).
17) Otte, S., Grobben, N. G., Robertson, L. A., Jetten M. S. M., and Kuenen J. G. : Nitrous oxide production by Alcaligenes faecalis under transient and dynamic aerobic and anaerobic conditions. Appl. Environ. Microbiol. 62: 2421-2426 (1996).

(Submitted 1998. 5. 14) (Accepted 1998. 7. 3) 